\title{
Consideration of Influential Factors on Bioleaching of Gold Ore Using Iodide-Oxidizing Bacteria
}

\author{
San Yee Khaing ${ }^{1}$, Yuichi Sugai ${ }^{2, *}$, Kyuro Sasaki $^{2}$ and Myo Min Tun ${ }^{3}{ }^{[}$ \\ 1 Department of Earth Resources Engineering, Graduate School of Engineering, Kyushu University, \\ Fukuoka 8190395, Japan; poeoo.34@mine.kyushu-u.ac.jp \\ 2 Department of Earth Resources Engineering, Faculty of Engineering, Kyushu University, \\ Fukuoka 8190395, Japan; krsasaki@mine.kuyushu-u.ac.jp \\ 3 Department of Geology, Yadanabon University, Mandalay 05063, Myanmar; mintunmyo@gmail.com \\ * Correspondence: sugai@mine.kyushu-u.ac.jp
}

Received: 11 April 2019; Accepted: 30 April 2019; Published: 2 May 2019

\begin{abstract}
Iodide-oxidizing bacteria (IOB) oxidize iodide into iodine and triiodide which can be utilized for gold dissolution. IOB can be therefore useful for gold leaching. This study examined the impact of incubation conditions such as concentration of the nutrient and iodide, initial bacterial cell number, incubation temperature, and shaking condition on the performance of the gold dissolution through the experiments incubating IOB in the culture medium containing the marine broth, potassium iodide and gold ore. The minimum necessary concentration of marine broth and potassium iodide for the complete gold dissolution were determined to be $18.7 \mathrm{~g} / \mathrm{L}$ and $10.9 \mathrm{~g} / \mathrm{L}$ respectively. The initial bacterial cell number had no effect on gold dissolution when it was $1 \times 10^{4}$ cells $/ \mathrm{mL}$ or higher. Gold leaching with IOB should be operated under a temperature range of $30-35^{\circ} \mathrm{C}$, which was the optimal temperature range for IOB. The bacterial growth rate under shaking conditions was three times faster than that under static conditions. Shaking incubation effectively shortened the contact time compared to the static incubation. According to the $\mathrm{pH}$ and redox potential of the culture solution, the stable gold complex in the culture solution of this study could be designated as gold (I) diiodide.
\end{abstract}

Keywords: iodide-oxidizing bacteria; bioleaching; gold; iodide; iodine; triiodide; gold diiodide

\section{Introduction}

Recovery of gold from ores and concentrates traditionally relies on cyanide leaching. Gold recovery with cyanidation process generally involves crushing, grinding, leaching, activated carbon adsorption, desorption, and electrowinning. However, cyanide leaching creates serious environmental risks due to its severe toxicity. Several cyanide substitutes have been suggested by some workers [1-4]. The iodine-iodide gold leaching is well known as an effective and environmental-friendly method for gold leaching without toxic chemicals such as cyanide, aqua regia and mercury [3,5]. According to Gos and Rubo (2001) [6], acute toxicity and ecotoxicity of cyanide are much higher than iodine. Cyanide is classified as a strong water contaminant however iodine is designated as slight water contaminant. The triiodide $\left(\mathrm{I}_{3}{ }^{-}\right)$is generated in the mixture of iodine $\left(\mathrm{I}_{2}\right)$ and iodide $\left(\mathrm{I}^{-}\right)$by the chemical reaction as shown by the Equation (1) [7].

$$
\mathrm{I}^{-}+\mathrm{I}_{2} \rightarrow \mathrm{I}_{3}^{-}
$$

Gold can be dissolved in the mixture of iodide and triiodide, forming gold (I) diiodide and/or gold (III) tetraiodide as shown by the Equations (2) and (3) respectively [7].

$$
2 \mathrm{Au}+\mathrm{I}_{3}{ }^{-}+\mathrm{I}^{-} \rightarrow 2\left[\mathrm{AuI}_{2}\right]^{-}
$$




$$
2 \mathrm{Au}+3 \mathrm{I}_{3}^{-} \rightarrow 2\left[\mathrm{AuI}_{4}\right]^{-}+\mathrm{I}^{-}
$$

Iodine-iodide gold leaching also has an advantage that the leaching system could be operated in a wide $\mathrm{pH}$ range ( $\mathrm{pH} 2$ to 10) [8], whereas the cyanide leaching should be operated under relatively restricted alkaline conditions ( $\mathrm{pH} 10$ to 11). Iodine-iodide gold leaching is however disadvantageous in the high cost for both iodine and iodide [9].

The application of microorganisms in metal solubilization processes has become more attractive than conventional pyrometallurgical and hydrometallurgical processes due to its low operating cost and eco-friendly nature [10]. Microorganisms have been applied in the commercial extraction of precious and base metals from primary ores and concentrate through biooxidation and bioleaching. Biooxidation has been utilized as a pre-treatment to dissolve sulfide minerals from refractory gold ores prior to conventional cyanide leaching [11-15]. Bioleaching refers to microbially catalyzed solubilization of metals from solid materials [16]. Iron- and sulfur-oxidizing acidophilic bacteria, such as Acidithiobacillus ferrooxidans and Acidithiobacillus thiooxidans, oxidize certain sulfidic ores which contain encapsulated particles of elemental gold, resulting in improved accessibility of gold to complexation by leaching agents such as cyanide [13]. In contrast, some microorganisms such as cyanogenic or amino acid-excreting microorganisms solubilize the elemental gold by the formation of gold-complexing metabolic products acting as biogenic lixiviants [13]. Bioleaching of gold by cyanogenic bacteria has been reported [17-20].

Kaksonen et al. [21] proposed the utilization of biogenic iodine-iodide lixiviant solution which was generated by iodide-oxidizing bacteria (IOB) for gold leaching. Khaing et al. [22] isolated IOB strains from environmental samples and demonstrated the gold dissolution from gold ore using the biogenic iodine-iodide lixiviant solution which was generated by IOB strains through the beaker-scale experiments. Iodide can be oxidized into iodine by IOB as shown by the microbial Equation (4) [23].

$$
2 \mathrm{I}^{-} \rightarrow \mathrm{I}_{2}+2 \mathrm{e}^{-}
$$

The underground brine water in natural gas fields in Japan contains iodide at $120 \mathrm{ppm}$, which is approximately 2000 times that of iodide concentration in sea water. Because of such high iodide concentration in this environment, many kinds of IOB inhabit the brine waters [24]. We therefore collected the brine samples from a natural gas field in Japan and successfully isolated eight bacterial strains of IOB from the brine samples in our previous study [22]. Those strains were then incubated in a liquid culture medium containing nutrients, iodide and gold ore whose gold grade and pulp density were $0.26 \mathrm{wt} \%$ and $3.3 \mathrm{w} / \mathrm{v} \%$ respectively under $30^{\circ} \mathrm{C}$. All the strains oxidized iodide into iodine and triiodide in the culture solution, resulting in gold dissolution from the ore as gold diiodide [22]. The best IOB strain dissolved gold from the ore completely within 5 days of incubation. However, the contact time of the gold bioleaching with IOB and iodide may not be as fast as that of gold leaching using cyanide, which was reported to be approximately $24-72 \mathrm{~h}$ for gold ore [7]. In addition, the costs of the nutrient and iodide may be expensive, which may be a significant cost factor to consider for the operation of the gold bioleaching with IOB and iodide. The influential factors for the bioleaching with IOB and iodide therefore should be carefully examined in order to improve its performance.

This study focused on determining the impact of incubation conditions such as the concentration of nutrient and iodide, incubation temperature, initial bacterial cell concentration and the shaking incubation on the performance of the gold dissolution from an ore sample through the incubation experiments which were carried out under variable conditions.

\section{Materials and Methods}

\subsection{Characteristics of the Ore}

The gold ore used in this study was sourced from the Modi Taung Gold Mine in Central Myanmar. The ore sample was crushed and ground to powder with an average particle diameter less than $75 \mu \mathrm{m}$. 
This powdered ore was used in the experiments of the present study. The chemical composition of the ore, as shown in Table 1, was determined by X-Ray Fluorescence (XRF, ZSX Primus II, Rigaku Corporation, Tokyo, Japan) analysis. The gold content in the ore was $0.26 \mathrm{wt} \%$. The ore microscopy and X-Ray Diffraction (XRD) analysis using Rigaku RINT-2100 Diffractometer (Rigaku Corporation, Tokyo, Japan), showed the presence of gold, galena, pyrite as the main phases, and sphalerite and chalcopyrite as the minor phase. Free visible gold $(>2 \mathrm{~mm})$ generally occurred as disseminated grains. The principal gangue mineral was quartz. Mitchell et al. [25] described that high gold values are clearly associated with high pyrite content in the veins.

Table 1. The chemical composition of the ground ore determined by XRF analysis.

\begin{tabular}{|c|c|c|c|c|c|c|c|c|c|c|c|c|c|}
\hline $\begin{array}{l}\text { Oxides \& } \\
\text { Elements }\end{array}$ & $\mathrm{SiO}_{2}$ & $\mathrm{SO}_{3}$ & $\mathrm{~Pb}$ & $\mathrm{Al}_{2} \mathrm{O}_{3}$ & $\mathrm{Fe}_{2} \mathrm{O}_{3}$ & $\mathrm{CaO}$ & $\mathrm{K}_{2} \mathrm{O}$ & $\mathrm{ZnO}$ & $\mathrm{Au}$ & $\mathrm{MgO}$ & Ag & $\mathrm{Cr}_{2} \mathrm{O}_{3}$ & LOI \\
\hline $\begin{array}{c}\text { Content } \\
(w t \%)\end{array}$ & 78.6 & 4.57 & 3.37 & 3.47 & 3.12 & 2.92 & 1.64 & 0.82 & 0.26 & 0.24 & 0.20 & 0.16 & 0.61 \\
\hline
\end{tabular}

\subsection{Characteristics of the IOB Strain}

The IOB strain which was selected as the most competent IOB strain through our previous study [22] was used in this study. This IOB strain was identified as Roseovarius tolerans by analyzing the sequences of its $16 \mathrm{~S}$ rRNA gene and named a-1 strain. $R$. tolerans is a heterotrophic, gram-negative bacterium belonging to $\alpha$-subclass of Proteobacteria that can oxidize iodide to iodine, and iodide-oxidizing reaction was mediated by extracellular oxidase that requires oxygen [24]. It was shown that the a-1 strain had an ability to complete the gold dissolution from the ore within 5 days of incubation in our previous study as described above.

\subsection{Culture Medium Preparation}

We examined the impact of incubation conditions on the growth of a-1 strain and the gold dissolution in this study. The reference conditions for the incubation experiments were as follows. Difco $^{\mathrm{TM}}$ Marine Broth 2216 (Becton, Dickinson and Company, Franklin Lakes, NJ, USA) was used as a nutrient for a-1 strain in this study. The culture medium for the reference contained the marine broth and potassium iodide at the concentration of $37.4 \mathrm{~g} / \mathrm{L}$ and $21.8 \mathrm{~g} / \mathrm{L}$ respectively. $15 \mathrm{~mL}$ of culture medium was poured into an $80 \mathrm{~mL}$ glass tube and lid with a silicone sponge plug. The culture medium was steam-sterilized under $12{ }^{\circ} \mathrm{C}$ for $20 \mathrm{~min}$. $0.5 \mathrm{~g}$ of ore powder which had been dry-sterilized under $140{ }^{\circ} \mathrm{C}$ for $4 \mathrm{~h}$ was put into the culture medium (pulp density was $3.3 w / v \%$ ).

The prescribed amount of preculture solution of a-1 strain was inoculated into the culture medium so that the initial bacterial cell number was set to $3.0 \times 10^{6}$ cells $/ \mathrm{mL}$ which was the reference initial bacterial cell concentration of this study. The preculture solution was obtained by incubating a-1 strain in the culture medium containing only the marine broth at the concentration of $37.4 \mathrm{~g} / \mathrm{L}$ at the temperature of $30^{\circ} \mathrm{C}$ under aerobic condition for a few days. Subsequently, the a- 1 strain in the culture medium was statically incubated in an incubator whose internal temperature was maintained at $30^{\circ} \mathrm{C}$ which was the reference incubation temperature of this study. The incubation time of this study was set to 10 days because it had been shown that the gold dissolution in the culture solution of a- 1 strain was completed within 5 days by our previous study [22].

The a-1 strain was incubated in the culture medium in which only the concentration of the marine broth was changed to 28.1, 18.7, 9.4 and $4.7 \mathrm{~g} / \mathrm{L}$ in order to examine the impact of the concentration of the marine broth on the bacterial growth and the gold dissolution. The a-1 strain was also incubated in the culture medium in which only the concentration of potassium iodide was changed to 16.4, $10.9,5.5$ and $2.2 \mathrm{~g} / \mathrm{L}$. The initial bacterial cell concentration of a- 1 strain was changed to $1.0 \times 10^{4}$ and $1.0 \times 10^{5}$ cells/mL respectively by changing the amount of inoculum whose bacterial cell number was known in order to examine the impact of initial bacterial cell concentration on the bacterial growth and the gold dissolution. The a-1 strain was incubated in the reference culture medium under 20, 35 
and $40{ }^{\circ} \mathrm{C}$ respectively in order to examine the impact of temperature on the bacterial growth and the gold dissolution. In those experiments, the a-1 strain was incubated in two glass tubes under the same condition to confirm the duplicability of results of the experiments. Lastly, the a-1 strain was incubated in the reference culture medium with the reference initial bacterial cell concentration under the reference temperature while being shaken. The shaking speed was $100 \mathrm{rpm}$. In this experiment, twenty-two glass tubes including two tubes which were non-inoculated (control) were prepared in order to understand the behavior of the growth of a- 1 strain and the gold dissolution under shaking conditions. Both solid samples and liquid samples were extracted from two tubes to confirm the duplicability of results of the experiments every day and those samples were subjected to various analyses as described below. The static incubation experiment was also carried out in parallel with the shaking incubation experiment.

\subsection{Analytical Procedures}

After the incubation, the bacterial cell number in the culture solution was directly counted with a Petroff-Hausser counting chamber using a phase-contrast microscope (EVOS XL Core Cell Imaging System, Thermo Fisher Scientific Inc., Waltham, MA, USA). After counting the bacterial cell number in the culture solution, the solid phase and liquid phase in the culture solution were separated by the filtration using a membrane filter with $0.2 \mu \mathrm{m}$ pore size. The solid sample on the membrane filter was washed with pure water and dried in an oven whose internal temperature was $50^{\circ} \mathrm{C}$ for a few days. The dried solid sample was subjected to XRF analysis to evaluate the gold content in itself. The leaching yield (\%) was calculated based on the XRF analysis using the following equation.

$$
L Y=\left(O M_{\mathrm{Au}}-F M_{\mathrm{Au}}\right) \times 100 / O M_{\mathrm{Au}}
$$

where $L Y$ is the leaching yield (\%), OM $\mathrm{Au}$ is the original mass of gold in the ore sample (g/g-ore) and $F M_{\mathrm{Au}}$ is the final mass of gold in the ore sample (g/g-ore). The leaching yield is usually calculated based on the mass of soluble gold in the leachate which is measured using ICP-MS/AES/OES or Atomic Absorption Spectrometry (AAS). However, it was calculated based on the mass of gold remaining in the solid phase in this study. Both soluble gold and gold remaining in the solid phase had been measured using ICP-MS and XRF respectively, and good balance between them had been obtained in our previous study [22]. The mass of residual gold which was measured using XRF can be, therefore, used for the evaluation of the leaching yield in this study.

The $\mathrm{pH}$ and redox potential of the filtrate were measured at room temperature using a handheld ion/pH meter (IM-32P, DKK-TOA Corporation, Tokyo, Japan). The reference electrode was a silver-silver chloride electrode in $3.3 \mathrm{~mol} / \mathrm{L}$ solution of potassium chloride.

\section{Results and Discussion}

\subsection{Impact of the Concentration of the Marine Broth and Potassium Iodide on the Bacterial Growth and the Leaching Yield}

Figure 1 shows the bacterial cell number (Figure 1a) and the leaching yield (Figure 1b) which were obtained in the incubation experiments under different concentration of the marine broth and potassium iodide. The bacterial cell number became higher as the concentration of the marine broth increased as shown in Figure 1a. In particular, the bacterial cell number increased up to $1 \times 10^{8} \mathrm{cells} / \mathrm{mL}$ or more in the culture solution whose initial concentration of the marine broth was $37.4 \mathrm{~g} / \mathrm{L}$. On the other hand, the bacterial cell number was little different with the variation in the concentration of potassium iodide. The concentration of the marine broth therefore has a significant influence on the growth of a-1 strain, whereas the concentration of potassium iodide has little influence on that.

The leaching yield was influenced by both concentrations as shown in Figure 1b. Gold was completely dissolved from the ore in the culture solution whose initial concentration of the marine broth and potassium iodide was higher than $18.7 \mathrm{~g} / \mathrm{L}$ and $10.9 \mathrm{~g} / \mathrm{L}$ respectively. The minimum necessary 
concentration of the marine broth and potassium iodide can be therefore assumed to be $18.7 \mathrm{~g} / \mathrm{L}$ and $10.9 \mathrm{~g} / \mathrm{L}$ respectively under the incubation conditions of this study. It was assumed that the leaching yield did not reach $100 \%$ in the other cases because iodine was not generated enough for the complete gold dissolution in those cases. When the concentration of the marine broth was $9.4 \mathrm{~g} / \mathrm{L}$ or less, the growth of a-1 strain was not so vigorous and the generation of iodine was also not so active. On the other hand, the amount of iodide which was the source for iodine was not enough for complete gold dissolution when the concentration of potassium iodide was $5.5 \mathrm{~g} / \mathrm{L}$ or less.

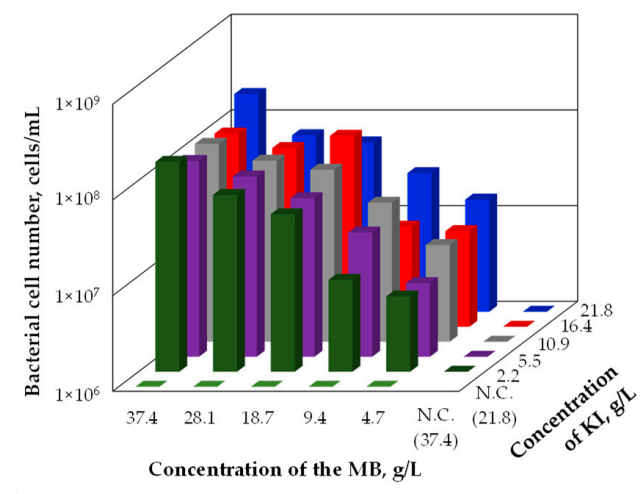

(a)

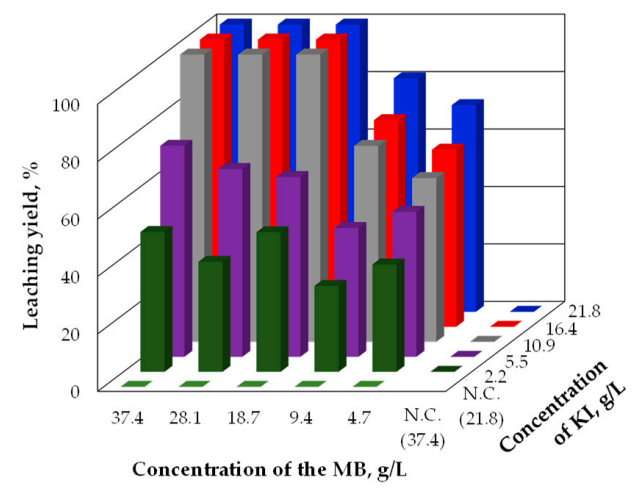

(b)

Figure 1. Effects of variable concentrations of marine broth (MB) and potassium iodide (KI) on (a) bacterial cell number and (b) gold leaching yield during 10 days of incubation experiment. Green bar: MB (37.4, 28.1, 18.7, 9.4 and $4.7 \mathrm{~g} / \mathrm{L})$ and KI (2.2 g/L), Purple bar: MB (37.4, 28.1, 18.7, 9.4 and $4.7 \mathrm{~g} / \mathrm{L})$ and KI (5.5 g/L), Gray bar: MB (37.4, 28.1, 18.7, 9.4 and $4.7 \mathrm{~g} / \mathrm{L})$ and $\mathrm{KI}(10.9 \mathrm{~g} / \mathrm{L})$, Red bar: MB $(37.4,28.1,18.7,9.4$ and $4.7 \mathrm{~g} / \mathrm{L})$ and $\mathrm{KI}(16.4 \mathrm{~g} / \mathrm{L})$, Blue bar: $\mathrm{MB}(37.4,28.1,18.7,9.4$ and $4.7 \mathrm{~g} / \mathrm{L})$ and $\mathrm{KI}$ $(21.8 \mathrm{~g} / \mathrm{L})$. The pulp density was $3.3 w / v \%$. N.C. is the negative control without inoculation of bacteria.

The mass of gold in a glass tube can be calculated as $0.0013 \mathrm{~g}$ from gold grade and the pulp density of the ore used in this study. Assuming that the minimum necessary concentration of the marine broth and potassium iodide is $18.7 \mathrm{~g} / \mathrm{L}$ and $10.9 \mathrm{~g} / \mathrm{L}$ respectively, it is calculated that $216 \mathrm{~g}$ of the marine broth and $126 \mathrm{~g}$ of potassium iodide are necessary for dissolving $1 \mathrm{~g}$ of gold from the ore. According to our market price investigation, the price of the marine broth and potassium iodide for industrial use is approximately 45,000 USD per $500 \mathrm{~kg}$ and $5400 \mathrm{USD}$ per $50 \mathrm{~kg}$ respectively. The cost of the minimum necessary amount of those chemicals for dissolving $1 \mathrm{~g}$ of gold from the ore can be calculated as 19.4 USD and 13.6 USD respectively. This result indicates that the cost performance of this method should be improved. In particular, the marine broth which was used in this study is a rich nutrient source containing 16 components such as peptone, yeast extract and inorganic substances and more costly compared to potassium iodide. It is therefore necessary to specify the effective components for IOB among the components in the marine broth and prepare the original nutrient source whose cost is cheaper. Moreover, it is also necessary to provide cheaper effective nutrient sources for IOB as an alternative to the marine broth.

\subsection{Impact of the Initial Bacterial Cell Number on the Bacterial Growth and the Leaching Yield}

The results of incubation experiments which were started with three different initial bacterial cell numbers are shown in Figure 2. Although the initial bacterial cell number was low such as $1.0 \times 10^{4}$ and $1.0 \times 10^{5}$ cells $/ \mathrm{mL}$, a- 1 strain grew and the bacterial cell number increased to $4.2 \times 10^{7}$ and $5.4 \times 10^{7}$ cells $/ \mathrm{mL}$ after 10 days incubation, which were approximately close to $1.2 \times 10^{8}$ cells $/ \mathrm{mL}$ which was the bacterial cell number in the reference condition. Gold was almost completely dissolved in all cases. Those results indicate that gold can be dissolved completely from the ore regardless of the initial bacterial cell number. In terms of practically of this method, it is an advantage to be able to start the incubation of a-1 strain with low initial bacterial cell concentration. 


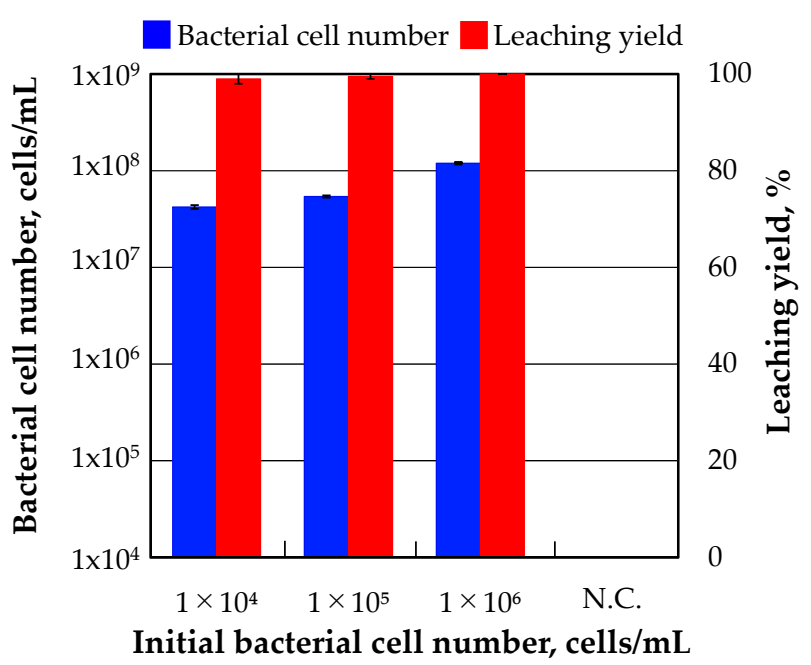

Figure 2. Effects of different initial bacterial cell numbers on the gold extraction during 10 days of incubation experiment. Initial bacterial cell numbers are set to $1 \times 10^{4}$ cells $/ \mathrm{mL}, 1 \times 10^{5}$ cells $/ \mathrm{mL}$ and $1 \times 10^{6}$ cells/mL respectively. Bacterial cell numbers (cells $/ \mathrm{mL}$ ) is shown by the left vertical axis whereas the leaching yield (\%) is indicated by the right vertical axis. N.C. is the negative control without inoculation of bacteria.

\subsection{Impact of Temperature on the Bacterial Growth and the Leaching Yield}

Figure 3 shows the results of the incubation experiments which were carried out under different temperature conditions. The highest bacterial cell number was observed in the culture solution which was incubated at $30^{\circ} \mathrm{C}$. The growth of a- 1 strain was also excellent at $35^{\circ} \mathrm{C}$, whereas it was poor at $25^{\circ} \mathrm{C}$ and $40{ }^{\circ} \mathrm{C}$. In particular, the growth of a-1 strain was significantly affected at $40{ }^{\circ} \mathrm{C}$ and the bacterial cell number after 10 days of incubation was less than $1.0 \times 10^{6}$ cells $/ \mathrm{mL}$. The same tendency was seen as the bacterial cell number with respect to the relation between the leaching yield and temperature. All gold contained in the ore was almost completely dissolved in the culture solution in which a- 1 strain was incubated at $30{ }^{\circ} \mathrm{C}$ and $35^{\circ} \mathrm{C}$ and more than $1 \times 10^{8}$ cells $/ \mathrm{mL}$ of bacterial cell number was observed. The leaching yield was $79 \%$ and $39 \%$ in the culture solution which was incubated at $20^{\circ} \mathrm{C}$ and $40^{\circ} \mathrm{C}$ respectively.

These results suggested that the gold dissolution depends on the activities of a- 1 strain in this study although the dissolution of elements from ore is generally promoted with the increase in temperature [26]. It is therefore important to operate the gold bioleaching with IOB and iodide under the optimal temperature for the activities of IOB. The bacterial activities are usually sensitive to temperature change. The optimal growth temperature of the species $R$. tolerans was reported as $33.5^{\circ} \mathrm{C}$ by [27]. The optimal temperature for the bacterial growth and the gold dissolution was also $30^{\circ} \mathrm{C}$ under the incubation conditions of this study. In particular, a significant difference of the bacterial growth and the gold dissolution was observed between the incubations at $35^{\circ} \mathrm{C}$ and $40^{\circ} \mathrm{C}$. The gold bioleaching with IOB and iodide should be therefore operated under the temperature between $30-35^{\circ} \mathrm{C}$.

\subsection{Impact of Shaking Condition on the Bacterial Growth and the Leaching Yield}

Figure 4 shows the temporal changes of the bacterial cell number and the leaching yield which were obtained by shaking and static incubation experiments. The bacterial cell number increased to $3.3 \times 10^{7}$ cells $/ \mathrm{mL}$ after 1 day of shaking incubation. The growth of a- 1 strain reached stationary phase after 3 days of shaking incubation and the maximum bacterial cell number reached $5.1 \times 10^{8}$ cells/mL at that time. The bacterial cell number was gradually decreased after that and became $1.5 \times 10^{8}$ cells $/ \mathrm{mL}$ after 10 days of shaking incubation. The leaching yield increased following the bacterial growth. The leaching yield began to increase after starting the shaking incubation and it increased to $7 \%, 43 \%$ and $78 \%$ after 1 days, 2 days and 3 days of shaking incubation respectively. 


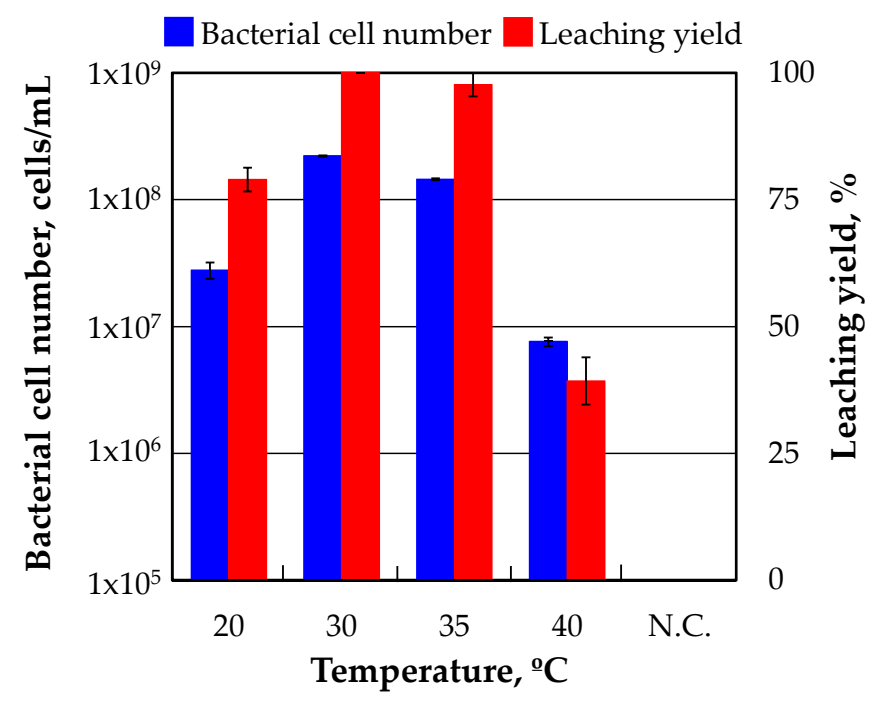

Figure 3. Effect of difference temperature conditions on the bacterial cell numbers and leaching yield during 10 days of incubation experiment. Bacterial cell numbers (cells/mL) is indicated by the left vertical axis with a logarithmic scale and error bars. The leaching yield (\%) is indicated by the right vertical axis with a linear scale and errors bars. N.C. is the negative control without inoculation of bacteria. The pulp density of the culture solution was $3.3 w / v \%$. The leaching yield was calculated by the Equation (5) by using the results of XRF analysis of the solid residue collected from culture solution after 10 days of incubation.

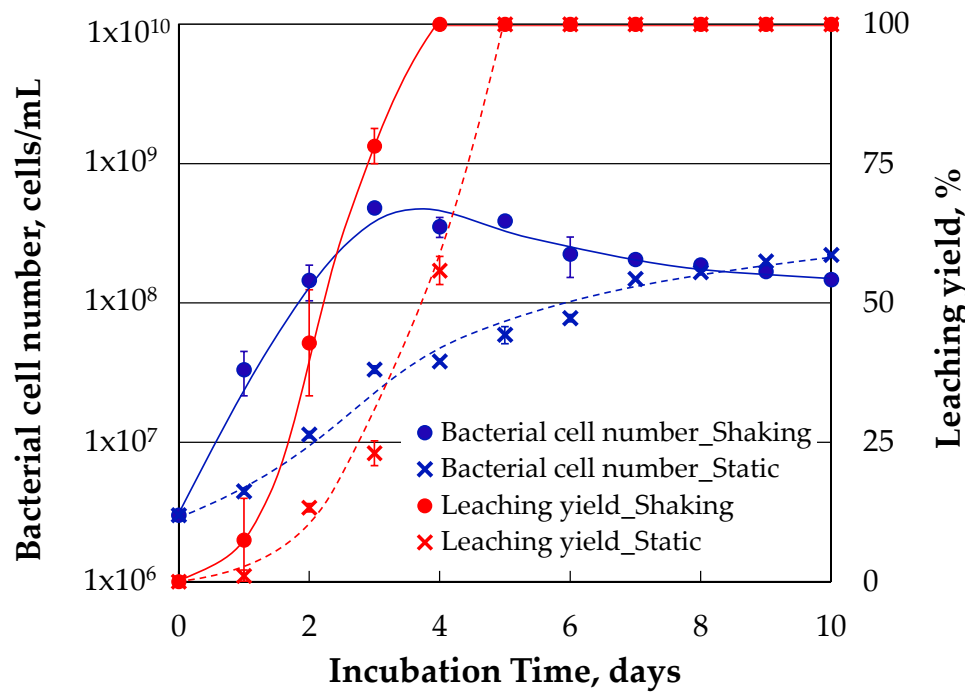

Figure 4. Temporal changes of bacterial cell numbers and Au leaching yield in the ore sample during shaking and static incubation experiments. Dynamic changes of bacterial cell number (blue circle) and Au leaching yield (red circle) from the ore sample in the culture solution with shaking effect. Bacterial cell number (blue cross) and Au leaching yield (red cross) from the ore sample in the culture solution without shaking effect. The bacterial cell number $(\mathrm{cells} / \mathrm{mL})$ is indicated in the left vertical axis with logarithmic scale. The Au leaching yield (\%) is shown by the right vertical axis with a linear scale.

On the other hand, both bacterial growth and leaching yield observed in the static incubation experiments were inferior to those observed in the shaking incubation experiments. The bacterial cell number of static incubation reached to the level equal to that of shaking incubation after 8 days of incubation. Also, the leaching yield reached to $100 \%$ after 5 days of static incubation, which was one day later than the time when the leaching yield reached to $100 \%$ in the shaking incubation. 
The impact of shaking condition on the bacterial growth and the leaching yield was quantitatively evaluated based on the growth rate and leaching rate which were calculated from the experimental results. Both growth rate and leaching rate were calculated using the bacterial cell number and the leaching yield obtained during the exponential growth phase because the incubation experiments were performed in closed system. Accordingly, the growth rates under shaking and static conditions were calculated using the bacterial cell numbers obtained during 0-3 days and 0-7 days respectively. Also, the leaching rates under shaking and static conditions were calculated using the leaching yields obtained during 1-4 days and 1-5 days respectively. The growth rates of a-1 strain under shaking and static conditions were 1.67 days $^{-1}$ and 0.56 days $^{-1}$, respectively. The growth rate under shaking condition was three times faster than that under static condition. The leaching rates of gold under shaking and static conditions were $0.41 \mathrm{mg} /$ day and $0.31 \mathrm{mg} /$ day, respectively. The difference between both leaching rates was not so large in comparison with the difference between both growth rates. In particular, the time before the growth of a- 1 strain had been started was shortened by shaking incubation and the gold dissolution was also started earlier than the start of the gold dissolution in static incubation. Shaking incubation can be effective to shorten the contact time of the gold bioleaching with IOB and iodide.

\subsection{Consideration of the Type of Dissolved Gold by the Measurement of $\mathrm{pH}$ and Redox Potential}

According to Angelidis et al. [7] and Baghalha [28], gold can be dissolved and stable in the iodine-iodide solution as gold (I) diiodide at the $\mathrm{pH}$ range of 0 to 13 and the redox potential range of 400 to $600 \mathrm{mV}$ respectively. When the redox potential of the solution is higher than $600 \mathrm{mV}$, gold is stable as gold (III) tetraiodide in the solution. The $\mathrm{pH}$ and redox potential of the culture solution were measured in order to understand the type of gold dissolved in the culture solution in this study.

The $\mathrm{pH}$ and redox potential of the culture solution which was incubated under the reference conditions for 10 days were 8.0 to 8.3 and $522 \mathrm{mV}$ to $547 \mathrm{mV}$ respectively, whereas those of the non-inoculated culture medium (control) was 7.1 and $173 \mathrm{mV}$ respectively. The type of gold in the culture solution could be therefore designated as gold (I) diiodide.

The $\mathrm{pH}$ and redox potential of the culture solution in which the complete gold dissolution was observed in the experiments changing the concentration of the marine broth $(18.7 \mathrm{~g} / \mathrm{L}$ to $37.4 \mathrm{~g} / \mathrm{L})$ and potassium iodide ( $10.9 \mathrm{~g} / \mathrm{L}$ to $21.8 \mathrm{~g} / \mathrm{L}$ ) were within a range of 7.8 to 8.2 and $512 \mathrm{mV}$ to $547 \mathrm{mV}$ respectively. Those of the culture solution which was incubated with initial bacterial cell number of $1 \times 10^{5}$ cells $/ \mathrm{mL}$ and $1 \times 10^{4}$ cells $/ \mathrm{mL}$ were within a range of 7.7 to 8.2 and $472 \mathrm{mV}$ to $546 \mathrm{mV}$ respectively. Those of the culture solution which was incubated at $30{ }^{\circ} \mathrm{C}$ to $35{ }^{\circ} \mathrm{C}$, which were the optimal temperature for the bacterial growth and the gold dissolution, were within a range of 8.0 to 8.1 and $501 \mathrm{mV}$ to $543 \mathrm{mV}$ respectively. Those of the culture solution which was incubated under shaking condition were 8.4 and $540 \mathrm{mV}$ respectively.

Thus, the $\mathrm{pH}$ and redox potential of the culture solution in which gold was completely dissolved from the ore were within a range of 7.7 to 8.4 and $472 \mathrm{mV}$ to $547 \mathrm{mV}$. The stable gold complex in the culture solution of the present study could be designated as gold (I) diiodide based on the $\mathrm{pH}$ and the redox potential of the culture solution.

\subsection{Comparison of the Present Study with Other Bioleaching Studies}

The present study and other bioleaching studies carried out by the application of some other microorganisms (Chromobacterium violaceum, Pseudomonas aeruginosa, Pseudomonas fluorescens, Acidithiobacillus sp., Aspergillus niger, Streptomyces setonii) were compared and shown in Table 2. Based on the result of the present study, gold can be solubilized completely from high-grade free milling ore having average particle size of $75 \mu \mathrm{m}$ within 10 days incubation experiment using the IOB-generated iodine-iodide lixiviant. The IOB method is promising due to high gold leaching yields obtained, and the possibility to have cyanide-free process. 
Table 2. Comparison of the gold bioleaching efficiency and process conditions from the present study with other gold bioleaching studies.

\begin{tabular}{|c|c|c|c|c|c|c|c|c|c|}
\hline Bacteria & $\begin{array}{c}\text { Particle Size of } \\
\text { Ore Sample, } \mu \mathrm{m}\end{array}$ & $\begin{array}{l}\text { Gold Source, } \\
\text { Pretreatment }\end{array}$ & $\begin{array}{l}\text { Pulp Density, } \\
w / v \%\end{array}$ & Nutrient, Nutrient Salts & $\begin{array}{c}\text { Leaching } \\
\text { Efficiency, \% }\end{array}$ & Temp., ${ }^{\circ} \mathrm{C}$ & $\begin{array}{l}\text { Initial Bacterial Cell } \\
\text { Number, Cells/mL }\end{array}$ & $\mathrm{pH}$ & Reference \\
\hline $\begin{array}{l}\text { Roseovarius } \\
\text { tolerans }\end{array}$ & $<75$ & $\begin{array}{l}\text { Sulfide ore with free } \\
\text { milling gold without } \\
\text { pretreatment }\end{array}$ & 3.3 & $\begin{array}{c}18.7 \mathrm{~g} / \mathrm{L} \text { Marine broth, } \\
10.9 \mathrm{~g} / \mathrm{L} \mathrm{KI}\end{array}$ & 100 & $30-35$ & $1 \times 10^{4}$ & $7.7-8.4$ & $\begin{array}{l}\text { This } \\
\text { study }\end{array}$ \\
\hline $\begin{array}{l}\text { Aspergillus } \\
\text { niger }\end{array}$ & $\begin{array}{l}10,000 \times 10,000 \\
\text { (rock block) }\end{array}$ & $\begin{array}{l}\text { Printed circuit boards } \\
\text { (PCBs) without } \\
\text { pretreatment }\end{array}$ & $3.8 \times 10^{-3}$ & $\begin{array}{c}50.0 \mathrm{~g} / \mathrm{L} \text { glucose, } 0.10 \mathrm{~g} / \mathrm{L} \mathrm{CaCl}_{2} \\
0.50 \mathrm{~g} / \mathrm{L} \mathrm{KH}_{2} \mathrm{PO}_{4}, 1.5 \mathrm{~g} / \mathrm{L} \mathrm{NH} \mathrm{Nl}_{4} \\
0.025 \mathrm{~g} / \mathrm{L} \mathrm{MgSO}_{4} \cdot 7 \mathrm{H}_{2} \mathrm{O}\end{array}$ & 87.0 & $28 \pm 2$ & - & $4.4-6.6$ & [29] \\
\hline $\begin{array}{l}\text { Chromobacterium } \\
\text { violaceum }\end{array}$ & $74-400$ & $\begin{array}{l}\text { PCBs biooxidized } \\
\text { by At. ferrooxidans }\end{array}$ & 0.5 & $0.98 \mathrm{~g} / \mathrm{L} \mathrm{MgSO}_{4} \cdot 7 \mathrm{H}_{2} \mathrm{O}$ & 70.6 & 30 & $2.3 \times 10^{14}$ & 11.0 & [20] \\
\hline $\begin{array}{l}\text { Chromobacterium } \\
\text { violaceum }\end{array}$ & $37-149$ & $\begin{array}{l}\text { Electronic waste } \\
\text { biooxidized by } \\
\text { At. ferrooxidans }\end{array}$ & 1.0 & - & 69.3 & 30 & - & $7.2-8.8$ & [19] \\
\hline $\begin{array}{l}\text { Chromobacterium } \\
\text { violaceum, } \\
\text { Pseudomonas } \\
\text { aeruginosa }\end{array}$ & $37-149$ & $\begin{array}{l}\text { Electronic waste } \\
\text { Biooxidized by } \\
\text { At.ferrooxidans }\end{array}$ & 1.0 & - & 73.2 & 30 & - & $7.2-9.2$ & [19] \\
\hline $\begin{array}{l}\text { Chromobacterium } \\
\text { violaceum, } \\
\text { Pseudomonas } \\
\text { fluorescens }\end{array}$ & $37-149$ & $\begin{array}{l}\text { Electronic waste } \\
\text { biooxidized by } \\
\text { At. ferrooxidans }\end{array}$ & 1.0 & - & 63.1 & 30 & - & $7.2-8.8$ & [19] \\
\hline $\begin{array}{l}\text { Chromobacterium } \\
\text { violaceum }\end{array}$ & $\begin{array}{l}1000 \times 1000 \\
(\text { rock block) }\end{array}$ & $\begin{array}{l}\text { Waste of mobile } \\
\text { phone PCBs without } \\
\text { pretreatment }\end{array}$ & 1.5 & $1.0 \mathrm{~g} / \mathrm{L} \mathrm{MgSO}_{4} \cdot 7 \mathrm{H}_{2} \mathrm{O}$ & 10.9 & 30 & - & $8.0-11.0$ & [18] \\
\hline $\begin{array}{l}\text { Streptomyces } \\
\text { setonii }\end{array}$ & 75 & $\begin{array}{l}\text { Refractory ore } \\
\text { biooxidized } \\
\text { by At. thiooxidan, } \\
\text { At. ferrooxidans, } \\
\text { and L. ferrooxidans } \\
\end{array}$ & 5.0 & $\begin{array}{c}5.0 \mathrm{~g} / \mathrm{L} \text { tryptone, } \\
3.0 \mathrm{~g} / \mathrm{L} \text { yeast extract, } 0.5 \mathrm{~g} / \mathrm{L} \mathrm{KCl}, \\
\mathrm{MgSO}_{4} \cdot 7 \mathrm{H}_{2} \mathrm{O}\end{array}$ & 94.7 & $23-37$ & - & $10.5-11.0$ & [11] \\
\hline $\begin{array}{l}\text { Acidithiobacillus } \\
\text { sp. }\end{array}$ & $<74$ & $\begin{array}{l}\text { Pyrrhotite refractory ore } \\
\text { without pretreatment }\end{array}$ & 50 & $\begin{array}{c}10,100 \mathrm{~g} / \mathrm{t} \mathrm{Ca}(\mathrm{OH})_{2} \\
16,000 \mathrm{~g} / \mathrm{t} \mathrm{NaCN}\end{array}$ & 19.7 & 25 & - & 11.0 & [30] \\
\hline $\begin{array}{l}\text { Acidithiobacillus } \\
\text { sp. }\end{array}$ & $<74$ & $\begin{array}{l}\text { Pyrrhotite refractory ore } \\
\text { biooxidized by } \\
\text { At.ferrooxidans }\end{array}$ & 50 & $\begin{array}{l}19,100 \mathrm{~g} / \mathrm{t} \mathrm{Ca}(\mathrm{OH})_{2} \\
22,000 \mathrm{~g} / \mathrm{t} \mathrm{NaCN}\end{array}$ & 91.0 & 25 & - & 11.0 & [30] \\
\hline $\begin{array}{l}\text { Acidithiobacillus } \\
\text { ferrooxidans }\end{array}$ & $20-125$ & $\begin{array}{l}\text { Arsenical refractory } \\
\text { sulfide concentrate } \\
\text { biooxidized by } \\
\text { At. ferrooxidans }\end{array}$ & 5.0 & $160,000 \mathrm{~g} / \mathrm{t} \mathrm{NaCN}$ & 85.2 & 35 & - & $10.5-12.0$ & [15] \\
\hline
\end{tabular}




\section{Conclusions}

This study focused on the bioleaching of gold from a gold ore by using IOB. The incubation experiments of an IOB strain were carried out using the culture medium containing the marine broth, potassium iodide and a gold ore under various conditions in order to obtain useful information about the influential factors for improving the performance of the bioleaching with IOB and iodide. Specifically, the impact of concentration of the marine broth and potassium iodide, initial bacterial cell number, incubation temperature, and shaking conditions on the growth of the IOB strain and the gold dissolution was evaluated through the incubation experiments in this study. The results obtained are summarized below.

The concentration of the marine broth and potassium iodide should be higher than $18.7 \mathrm{~g} / \mathrm{L}$ and $10.9 \mathrm{~g} / \mathrm{L}$ respectively in order to dissolve gold completely from the ore used in this study. From these results, it was calculated that $216 \mathrm{~g}$ of the marine broth and $126 \mathrm{~g}$ of potassium iodide are necessary for dissolving $1 \mathrm{~g}$ of gold from the ore. The cost of those chemicals required for dissolving $1 \mathrm{~g}$ of gold from the ore was calculated as 33 USD on the basis of their price for industrial use. Thus, the cost performance of this method should be further improved by screening the effective components from among the components in the marine broth and/or searching for cheaper effective nutrient sources as alternatives to the marine broth.

When the initial bacterial cell number was $1 \times 10^{4}$ cells/mL or higher, the initial bacterial cell number had no significant impact on the growth of the IOB strain and the gold dissolution. The operation of bioleaching with the IOB strain and iodide can be started with low bacterial cell numbers.

Gold contained in the ore was almost completely dissolved in the culture solution incubated at $30{ }^{\circ} \mathrm{C}$ and $35^{\circ} \mathrm{C}$, therefore, the optimal temperature for the growth of the IOB strain and the gold dissolution was within a range of those temperatures. The operation of the bioleaching with IOB and iodide should be operated within temperature range between $30^{\circ} \mathrm{C}$ and $35^{\circ} \mathrm{C}$.

The bacterial growth of the IOB strain was promoted under shaking condition. The growth rate of the IOB strain under shaking condition was three times higher than that under static condition. Accordingly, the gold dissolution was also promoted under shaking condition.

The $\mathrm{pH}$ and redox potential of the culture solution in which complete gold dissolution was observed were within a range of 7.7 to 8.4 and $472 \mathrm{mV}$ to $547 \mathrm{mV}$. The stable gold complex in the culture solution of this study could be designated as gold (I) diiodide.

The only competitor of IOB to obtain iodide-triiodide for gold leaching is the chemical iodine-iodide leaching. Previous study [22] and the present study proved that gold-bioleaching is as effective as chemical iodine leaching. Gold can be recovered completely after 5 days of incubation. However, bacterial leaching of gold using IOB compares unfavorably with chemical iodine-iodide leaching because it is a slower process and the leaching (contact) time may not be as fast as that of direct chemical leaching. In practice, the costs of the reagents iodine and iodide are quite high. Even though gold leaching rate or dissolution in iodine-iodide solution is proved to be much faster than in conventional cyanidation process [2,31], iodine-iodide processing of gold is under-utilized and insufficiently explored mainly due to its high cost [2]. However, one advantage is that, in bioleaching operation using IOB, iodine can possibly be recovered at the end of leaching processes. Only the cost of nutrients (marine broth) and KI must be taken into account. To the best of our knowledge, there are no other ways to produce iodide-triiodide.

Author Contributions: S.Y.K. and Y.S. designed the study and carried out all the experiments. Y.S., K.S. and M.M.T. helped with sample collection, sample analyses and valuable discussions. S.Y.K. and Y.S. wrote and completed the manuscript considering the review comments provided by all authors.

Funding: This research was funded by a grant entitled "Engineering Research for Pioneering of a New Field" provided by the Faculty of Engineering, Kyushu University, Japan. This work was also supported by JSPS KAKENHI Grant Number JP19K05352.

Acknowledgments: We thank U Tin Tun and U Myint Thein Htay, the geologists of Modi Taung Gold Mine (Myanmar) for their supports during the geological excursion for our ore sample collection. 
Conflicts of Interest: The authors declare no conflict of interest.

\section{References}

1. Mc Nulty, T. Cyanide substitutes. Min. Mag. 2001, 184, 256-261.

2. Hilson, G.; Monhemius, A.J. Alternatives to cyanide in the gold mining industry: What prospects for the future? J. Clean. Prod. 2006, 14, 1158-1167. [CrossRef]

3. Gökelma, M.; Birich, A.; Stopic, S.; Friedrich, B. A review on alternative gold recovery reagents to cyanide. J. Mater. Sci. Chem. Eng. 2016, 4, 8-17. [CrossRef]

4. Aylmore, M. Alternative lixiviants to cyanide for leaching gold ores. In Gold Ore Processing: Project Development and Operations; Adams, M.D., Ed.; Elsevier: Amsterdam, The Netherland, 2016; pp. 447-484.

5. Lucheva, B.; Iliev, P.; Kolev, D. Recovery of Gold from Electronic Waste by Iodine-iodide Leaching. J. Chem. Tech. Metall. 2017, 52, 326-332.

6. Gos, S.; Rubo, A. The Relevance of Alternative Lixiviants with Regard to Technical Aspects, Work Safety and Environmental Safety. Cyplus. Degussa AG, Hanau, Germany 2001. Available online: http://citeseerx.ist.psu. edu/viewdoc/download?doi=10.1.1.596.4536\&rep=rep1\&type=pdf (accessed on 1 May 2019).

7. Angelidis, T.N.; Kydros, K.A.; Matis, K.A. A fundamental rotating disk study of gold dissolution in iodine-iodide solutions. Hydrometallurgy 1993, 34, 49-64. [CrossRef]

8. Qi, P.H.; Hiskey, J.B. Dissolution kinetics of gold in iodide solution. Hydrometallurgy 1991, $27,47-62$. [CrossRef]

9. Yannopoulos, J.C. The Extractive Metallurgy of Gold; Van Nostrand Reinhold: New York, NY, USA, 1991.

10. Johnson, D.B. Biodiversity and interactions of acidophiles: Key to understanding and optimizing microbial processing of ores and concentrates. Trans. Nonferrous Met. Soc. China 2008, 18, 1367-1373. [CrossRef]

11. Amankwah, R.K.; Yen, W.T.; Ramsay, J.A. A two-stage bacterial pretreatment process for double refractory gold ores. Miner. Eng. 2005, 18, 103-108. [CrossRef]

12. Lindstrom, E.B.; Gunneriusson, E.; Tuovinen, O.H. Bacterial Oxidation of Refractory Sulfide Ores for Gold Recovery. Crit. Rev. Biotechnology 2008, 12, 133-155. [CrossRef]

13. Olson, G.J. Microbial oxidation of gold ores and gold bioleaching. FEMS Microbiol. Lett. 1994, 119, 1-6.

14. Komnitsas, C.; Pooley, F.D. Mineralogical characteristics and treatment of refractory gold ores. Miner. Eng. 1989, 2, 449-457. [CrossRef]

15. Komnitsas, C.; Pooley, F.D. Bacterial oxidation of an arsenical gold sulphide concentrate from Olympias, Greece. Miner. Eng. 1990, 3, 295-306. [CrossRef]

16. Watling, H. Review microbiological advances in biohydrometallurgy. Minerals 2016, 6, 49. [CrossRef]

17. Reith, F.; Lengke, M.F.; Falconer, D.; Craw, D.; Southam, G. The geo-microbiology of gold. ISME J. 2007, 1, 567-584. [CrossRef]

18. Tran, C.D.; Lee, J.C.; Pandey, B.D.; Jeong, K.K.; Jinki, Y. Bioleaching of gold and copper from waste mobile phone PCBs by using a cyanogenic bacterium. Miner. Eng. 2011, 24, 1219-1222.

19. Pradhan, J.K.; Kumar, S. Metals bioleaching from electronic waste by chromobacterium violaceum and Pseudomonads sp. Waste Manag. Res. 2012, 30, 1151-1159. [CrossRef]

20. Li, J.; Liang, C.; Ma, C. Bioleaching of gold from waste printed circuit boards by Chromobacterium violaceum. J. Mater. Cycles Waste Manag. 2015, 17, 529-539. [CrossRef]

21. Kaksonen, A.H.; Mudunuru, B.M.; Hackl, R. The role of microorganisms in gold processing and recovery-A review. Hydrometallurgy 2014, 142, 70-83. [CrossRef]

22. Khaing, S.Y.; Sugai, Y.; Sasaki, K. Gold Dissolution from Ore with Iodide-Oxidising Bacteria. Sci. Rep. 2019, 9, 4178. [CrossRef]

23. Effenberger, J.A. Reactions of iodine and iodide ions in the presence and absence of polysaccharides. Retrosp. Theses Diss. 1961. [CrossRef]

24. Amachi, S.; Muramatsu, Y.; Akiyama, Y.; Miyazaki, K.; Yoshiki, S.; Hanada, S.; Kamagata, Y.; Ban-nai, T.; Shinoyama, H.; Fujii, T. Isolation of iodide-oxidizing bacteria from iodide-rich natural gas brines and seawaters. Microb. Ecol. 2005, 49, 547-557. [CrossRef] [PubMed]

25. Mitchell, A.H.G.; Ausaa, C.A.; Deiparinea, L.; Hlaingb, T.; Htayc, N.; Khinec, A. The Modi Taung-Nankwe gold district, Slate belt, central Myanmar: Mesothermal veins in a Mesozoic orogeny. J. Asian Earth Sci. 2004, 23, 321-341. [CrossRef] 
26. Deveci, H.; Akcil, A.; Alp, I. Parameters for control and optimization of bioleaching of sulfide minerals. In Process Control and Optimization in Ferrous and Non Ferrous Industry, Material Science E Techology Symposium; Kongoli, F., Thomas, B., Sawamiphakdi, K., Eds.; TMS: Pittsburgh, PA, USA, 2003; pp. 77-90.

27. Labrenz, M.; Collins, M.D.; Lawson, P.A.; Tindall, B.J.; Schumann, P.; Hirsch, P. Roseovarius tolerans gen. nov., sp. nov., a budding bacterium with variable bacteriochlorophyll a production from hypersaline Ekho Lake. Int. J. Syst. Bacteriol. 1999, 49, 137-147. [CrossRef] [PubMed]

28. Baghalha, M. The leaching kinetics of an oxide gold ore with iodide/iodine solution. Hydrometallurgy 2012, 113-114, 42-50. [CrossRef]

29. Madrigal-Arias, J.E.; Argumedo-Delira, R.; Alarcón, A.; Mendoza-López, M.R.; García-Barradas, O.; Cruz-Sánchez, J.S.; Ferrera-Cerrato, R.; Jiménez-Fernández, M. Bioleaching of gold, copper and nickel from waste cellular phone PCBs and computer goldfinger motherboards by two Aspergillus niger strains. Brazil. J. Microbio. 2015, 46, 707-713. [CrossRef]

30. Ubaldini, S.; Veglio, F.; Beolchini, F.; Toro, L.; Abbruzzese, C. Gold recovery from a refractory pyrrhotite ore by biooxidation. Int. J. Miner. Process 2000, 60, 247-262. [CrossRef]

31. Wang, H.X.; Sun, C.B.; Li, S.V.; Fu, P.F.; Song, Y.G.; Li, L.; Xie, W.Q. Study on gold concentrate leaching by iodine-iodide. Int. J. Miner. Metall. Mater. 2013, 20, 323-328. [CrossRef]

(C) 2019 by the authors. Licensee MDPI, Basel, Switzerland. This article is an open access article distributed under the terms and conditions of the Creative Commons Attribution (CC BY) license (http://creativecommons.org/licenses/by/4.0/). 